\title{
Basal expression effect
}

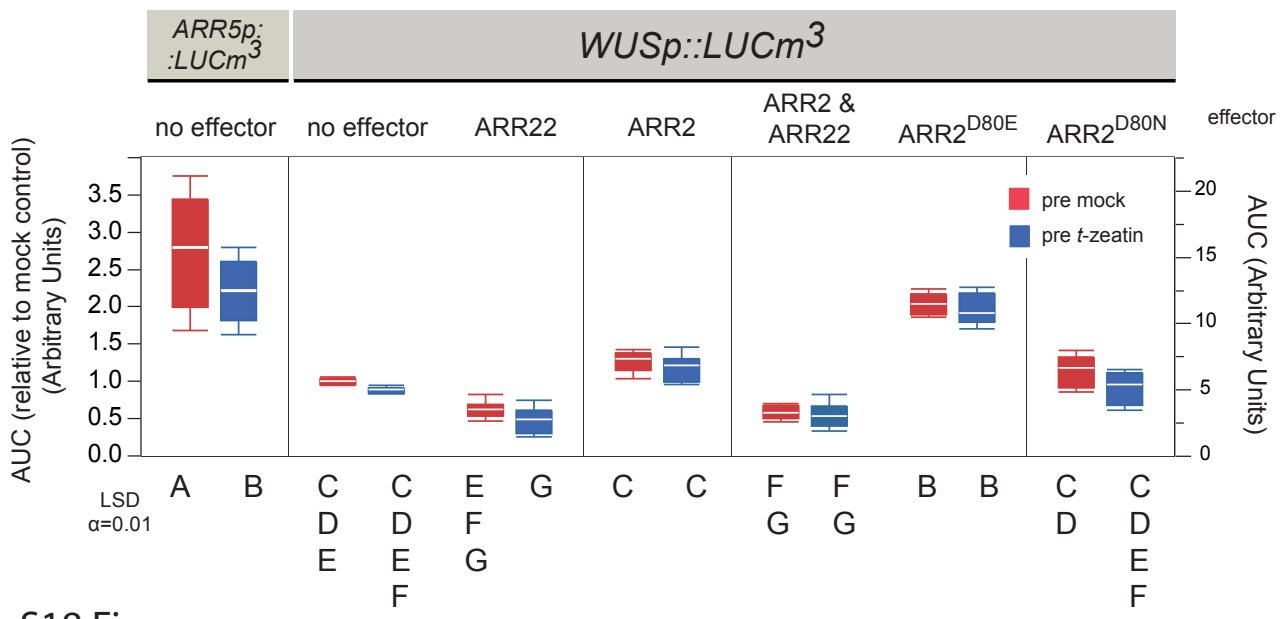

S18 Fig

G 